\title{
Does sediment grain size affect diatom grazing by harpacticoid copepods?
}

\author{
Marleen De Troch ${ }^{\mathrm{a}, *}$, Lieven Houthoofd ${ }^{\mathrm{a}}$, Victor Chepurnov ${ }^{\mathrm{b}}$, \\ Ann Vanreusel ${ }^{\mathrm{a}}$ \\ ${ }^{a}$ Ghent University, Biology Department, Marine Biology Section, \\ Campus Sterre, Krijgslaan 281 - S8, B-9000 Gent, Belgium \\ ${ }^{\mathrm{b}}$ Ghent University, Biology Department, Protistology and Aquatic Ecology, \\ Campus Sterre, Krijgslaan 281 - S8, B-9000 Gent, Belgium
}

Received 8 September 2005; received in revised form 25 October 2005; accepted 26 October 2005

\begin{abstract}
Estuarine soft sediments support a diverse group of eukaryotic and prokaryotic organisms though the role of the sediment per se for the functioning of these organisms remains largely unknown. The present study aimed to test the effect of sediment grain size on the grazing activities of harpacticoid copepods. In controlled experiments, two common intertidal harpacticoid species (Paramphiascella fulvofasciata and Nitokra spinipes) were each offered a mix of two benthic diatom species (Navicula phyllepta and Seminavis robusta) in different sedimentary conditions. Several microcosms were created using a variety of sediment types, including fine silt $(<63 \mu \mathrm{m})$, coarser grained sands $(125-250,250-450,100-300 \mu \mathrm{m})$, artificial 'sediments' of glass beads $(250-500,2000 \mu \mathrm{m})$ and even the absence of sediment was tested. The diatoms were enriched in the stable carbon ${ }^{13} \mathrm{C}$ to facilitate tracing in the harpacticoids. Both copepod species were able to graze on the diatoms with highest uptake when sediment was absent. In contrast, both harpacticoid species showed no uptake in silty conditions. In general, grazing was favoured when mean sediment grain size increased. The strong negative effect of fine grains on the grazer's efficiency can be explained by the resulting differences in the structure (and accessibility) of the diatom biofilm on the one hand and the mobility of the grazer on the other hand. In view of the subtle equilibrium between primary producers and grazers, these results might have important implications for the effect of siltation of tidal flats due to, e.g., human activities.
\end{abstract}

(C) 2005 Elsevier Ltd. All rights reserved.

\footnotetext{
* Corresponding author. Fax: +329264 8598 .

E-mail address: marleen.detroch@ugent.be (M. De Troch).
} 
Keywords: Copepoda; Diatoms; Grazing; Sediment

\section{Introduction}

Estuarine soft sediments such as sand and silt, support a diverse group of eukaryotic and prokaryotic organisms (e.g., Underwood \& Paterson, 1993). The shallow waters of these coastal systems provide sufficient irradiance for the growth of photosynthetic prokaryotes, protists and vascular plants (Reise, 2002). The total primary production in estuarine and shallow water ecosystems is significantly attributable to the activity of microphytobenthos (Underwood \& Kromkamp, 1999). Pennate diatoms dominate the estuarine microphytobenthic flora (Round, Crawford, \& Mann, 1990; Smith \& Underwood, 1998) and are known as an important link in the benthic food chain. Although the importance of microphytobenthos to the functioning of shallow ecosystems has been well established (Heip et al., 1995), there is still uncertainty and little information on its fate: the microalgae in the sediment may be resuspended, mixed to deeper layers or consumed by heterotrophs or grazers (Middelburg et al., 2000). Meiofaunal grazers such as nematodes (Galluci, Steyaert, \& Moens, in press and references herein) and copepods form the major meiofaunal taxa resident in these shallow water sediments and graze at a rate of $1 \%$ of the microbial standing stock of both heterotrophs and autotrophs per hour worldwide (Montagna, 1995).

Copepods or small crustaceans are a popular subject of research in marine biology and ecology in determining the role of grazers in aquatic food webs. They play an indispensable role in transferring energy from primary producers to top trophic levels (e.g., BuffanDubau \& Carman, 2000; De Troch, Mees, \& Wakwabi, 1998; Sogard, 1984).

In order to reveal the basic energy flows of benthic ecosystems, most to all studies involved laboratory experiments with cultured harpacticoid copepods reared on a variety of food sources, e.g., microalgae (Carman \& Thistle, 1985; De Troch, Steinarsdóttir, Chepurnov, \& Ólafsson, 2005), protozoans (Rieper \& Flotow, 1981), bacteria (Rieper, 1978, 1982) and flesh (Fetcher, Thistle, Arlt, Suderman, \& Vopel, 2004; Guidi, 1984; Lopez, 1982; Seifried \& Dürbaum, 2000). The laboratory lay-out however, imposes strong constraints on the extrapolation of the resulting data to field situations. So far, the importance of biogenic (vascular plants, algae, carbonate shells) and abiotic (silt, sand, rocks) structuring elements in marine benthic communities is well recognised (Reise, 2002 and references therein). However, a key-question in unraveling benthic communities remains whether these communities are primarily structured by trophic interactions or rather by the biotic habitat where they occur (Reise, 2002). Moreover, both factors can interact with each other and hamper our knowledge on sediment mediated species interactions. For example, the effect of suspended sediment on suspension feeders is well known (e.g., Ellis, Cummings, Hewitt, Thrush, \& Norkko, 2002). Changes in sediment characteristics may also modify feeding and distributions of grazers, and lower water clarity may affect the quantity, type and depth to which bottom-living microscopic algae and seaweeds can grow. The effect of sediment characteristics on grazers is however far from well documented.

In this study, we conducted a laboratory copepod feeding experiment with a simple experimental set-up and short duration in order to control the plethora of factors that may 
affect harpacticoid grazing on diatoms. We tested if soft sediment grain size and structure affect the uptake of diatoms by harpacticoid copepods. We hypothesized that the uptake or feeding would be favoured in sediment-free and/or large grain size sedimentary situations since grazing might be facilitated on freely exposed biofilms and large sediment grain surface covered by diatoms, respectively. In controlled laboratory experiments we used two benthic harpacticoid copepod species as grazers and fed these on diets composed of two benthic diatom species enriched in ${ }^{13} \mathrm{C}$ in order to facilitate tracing. We further discuss the possible ecological implications of sedimentology for grazers on diatom biofilms.

\section{Materials and methods}

\subsection{Sediment sampling and processing}

Sediment samples were collected from different sites of the Paulina intertidal flat in the Westerschelde Estuary, SW Netherlands $\left(51^{\circ} 21^{\prime} \mathrm{N}, 3^{\circ} 43^{\prime} \mathrm{E}\right)$. After drying at $60^{\circ} \mathrm{C}$ overnight, these samples were sieved over a 'tower' of 1000, 450, 250, 125 and $63 \mu \mathrm{m}$ mesh size sieves. This resulted in three treatments using the following sediment grain size fractions: smaller than $63 \mu \mathrm{m}$ (silt), between 125 and $250 \mu \mathrm{m}$ (fine sand) and between 250 and $450 \mu \mathrm{m}$ (coarse sand). Per fraction, mean grain sizes were analysed using a Coulter LS Particle Size Analyser (Table 1). Each fraction was put in a high temperature oven $\left(4 \mathrm{~h}\right.$ at $\left.550{ }^{\circ} \mathrm{C}\right)$ for sterilization and combustion of remaining organic matter. Three additional treatments were set up by using sterile sand (Merck, grain size between 0.1 and $0.3 \mathrm{~mm}$ ) and glass beads (Merck) of 250-500 (fine) and $2000 \mu \mathrm{m}$ (coarse) in diameter.

\subsection{Laboratory conditions and labeling technique}

Two common intertidal benthic harpacticoid copepod species were cultured in the laboratory: Nitokra spinipes (family Ameiridae, collected from Paulina intertidal flat) and Paramphiascella fulvofasciata (family Diosaccidae, collected from German intertidal mudflats). The former reaching sizes of $0.66-0.8 \mathrm{~mm}$ and a carbon content of $14.7 \pm 0.4 \mu \mathrm{g} \mathrm{C}$, the latter reaching sizes up to $0.83 \mathrm{~mm}$ and a carbon content of $15.6 \pm 0.6 \mu \mathrm{g} \mathrm{C}$ (De Troch et al., 2005). There is no detailed information available on the range of sedimentary conditions the species can tolerate under field conditions. In a tidal flat, there is typically a wide range of sediment conditions. In the Paulina intertidal flat (SW Netherlands) we collected copepods from muddy sediment.

These two benthic copepod species were cultured in the laboratory in artificial seawater of 30-32 psu. All copepod cultures were stored in glass beakers of about 11 and regularly provided with a mixture of diatoms and detrital matter. This food mixture contained, amongst others, the diatoms used in the experiment.

Table 1

Statistical parameters of granulometric analysed sediment fractions (in $\mu \mathrm{m}$ )

\begin{tabular}{lcccc}
\hline & Mean & SD & Median & Variance \\
\hline$<63 \mu \mathrm{m}$ (silt) & 26.63 & 2.714 & 36.52 & 7.365 \\
$125-250 \mu \mathrm{m}$ (fine) & 222.1 & 1.266 & 222.9 & 1.603 \\
$250-450 \mu \mathrm{m}$ (coarse) & 316.7 & 1.300 & 317.9 & 1.690 \\
\hline
\end{tabular}


Diatoms were provided by the Laboratory of Protistology and Aquatic Ecology (PAE, Ghent University). For the experiments, two benthic diatom species, Navicula phyllepta (Nav(III)(P-06), Fig. 1A, further referred to as Navicula) and a Seminavis robusta clone (voucher Sem-F1-8A, Chepurnov, Mann, Vyverman, Sabbe, \& Danielidis, 2002, Fig. 1B, further referred to as Seminavis), were cultured in $\mathrm{f} 2$ medium (seawater with additional nutrients, Guillard, 1975) and enriched with ${ }^{13} \mathrm{C}$ by replacing $\mathrm{NaH}^{12} \mathrm{CO}_{3}$ with $\mathrm{NaH}^{13} \mathrm{CO}_{3}$ when preparing the $\mathrm{f} 2$ medium. For this, $5 \mathrm{ml}$ of a stock solution of $336 \mathrm{mg} \mathrm{NaH}{ }^{13} \mathrm{CO}_{3}$ in $100 \mathrm{ml}$ milliQ $\mathrm{H}_{2} \mathrm{O}$ was added to the culture medium. This enrichment resulted in isotope signatures $\left(\delta^{13} \mathrm{C}\right)$ of $-3 \%$ and $15,419 \%$ for Navicula (no isotopic signatures were measured for Seminavis) for untreated and ${ }^{13} \mathrm{C}$ enriched cultures, respectively. This labeled $\mathrm{f} 2$ medium was gently washed away and replaced by artificial seawater prior to the feeding experiments. Biovolume of diatoms was calculated following Hillebrand, Dürselen, Kirschtel, Pollingher, and Zohary (1999), by means of digital photographs taken with an Olympus DP50 camera coupled to a type Leitz Diaplan microscope. Average biovolumes of Seminavis and Navicula were 1980 and $323 \mu^{3}$, respectively. Copepods were sorted from the original stock cultures, starved overnight and washed in artificial seawater (to remove all food and faecal pellet particles) prior to placing them in the experimental units.

Copepod and diatom cultures were kept in the same climate room at $15-18^{\circ} \mathrm{C}$ under a light regime of 12:12 h light-dark. The experiment was conducted in small petri-plates (diameter $=5.2 \mathrm{~cm}$, effective surface $=21.2 \mathrm{~cm}^{2}$ ) filled with $15 \mathrm{ml}$ of artificial seawater (controls). For the sediment treatments, small petri-plates (same dimensions as controls) were first filled with a fixed amount of weighed sediment $(9 \mathrm{~g}$ each for each treatment; $4 \mathrm{~g}$ for the $<63 \mu \mathrm{m}$ treatment). Subsequently artificial seawater was added according to the height of the water in the control treatments, i.e., approximately $10 \mathrm{ml}$ was added. Petri-plates were put in the dark and remaining floating sediment particles could sink and settle overnight. In all treatments a total of approx. 400,000 live diatom cells (200,000 cells of each diatom species) were offered as food by gently spreading them with a micro-pipette over the sediment surface in order to create a biofilm. Therefore, all treatments were left for a couple of hours in order to let diatoms settle down. Especially Seminavis was observed to form a tight biofilm within 10-15 min after suspension (by shaking) when they rapidly attached to the substratum (De Troch \& Chepurnov, pers. observ.).
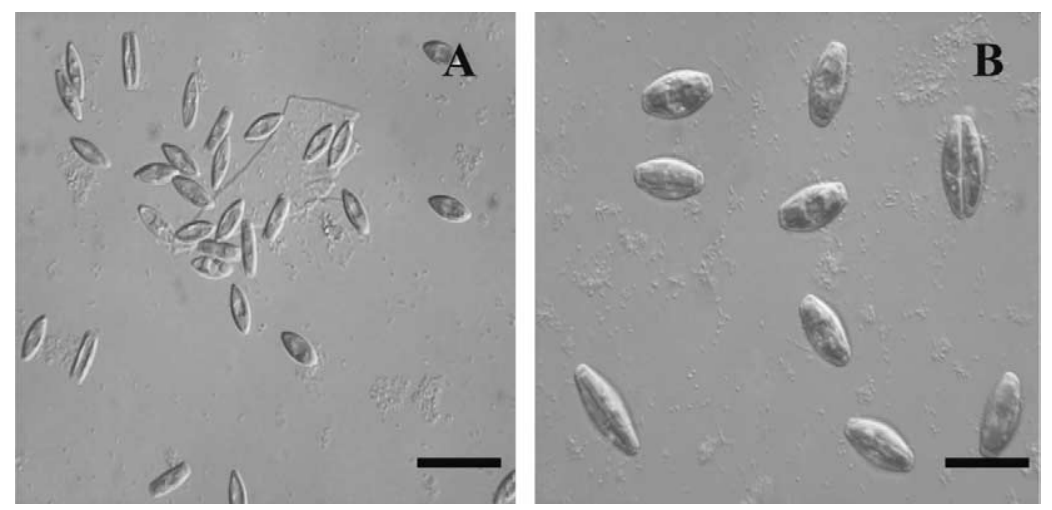

Fig. 1. Diatoms used in the experiment: (A) Seminavis robusta, (B) Navicula phyllepta (scale bar $=20 \mu \mathrm{m})$. 


\subsection{Experimental design}

Experiments with $P$. fulvofasciata and $N$. spinipes were conducted using seven different treatments: a control treatment without sediment (without), two treatments with glass beads of 250-500 (fine glass, Fig. 2C) and 2000 $\mu \mathrm{m}$ (coarse glass, Fig. 2B) in diameter, a treatment with sterile sand (sterile sand, Fig. 2A) and three treatments with sediment fractions $<63 \mu \mathrm{m}$ (silt, Fig. 2F), 125-250 $\mu \mathrm{m}$ (fine sand, Fig. 2E) and 250-450 $\mu \mathrm{m}$ (coarse sand, Fig. 2D). In addition, a control without sediment and diatoms (control, for measuring the natural isotopic composition of the copepods) was analysed. For all experiments, each treatment was replicated three times and was conducted for the two copepod species separately. In order to accurately detect ${ }^{13} \mathrm{C} /{ }^{12} \mathrm{C}$ ratios in the tissue of the harpacticoids, a minimum of $15 \mu \mathrm{g} \mathrm{C}$ was analysed corresponding to 20 and 30 adults of $P$. fulvofasciata and $N$. spinipes, respectively. All experimental units (petri-plates) were placed randomly on a tray in the climate room for 4 days. The duration of the experiment was based on the outcome of an earlier experiment to test the temporal uptake of diatoms by harpacticoids. It was shown that after 4 days $(96 \mathrm{~h})$ a stable, measurable ${ }^{13} \mathrm{C}$ enrichment could be traced (De Troch et al., 2005).

\subsection{Analytic technique and data treatment}

Petri-plates containing the copepods for natural isotopic signature measurements were put in the freezer at the start of the experiment. The experiment ran for 4 days and was ended by placing all experimental units in the freezer for further analysis. Afterwards, copepods were hand-sorted and counted, washed several times in deionised water and placed in tin capsules $(8 \times 5 \mathrm{~mm}$, Elemental Microanalysis Limited) by means of a needle. This sorting of copepods was done within $2 \mathrm{~h}$ of thawing in order to prevent or minimise leakage of label after thawing as reported for other meiofaunal taxa by Mourelatos, Rougier, and Lacroix (1992) (cladocerans) and Moens, Van Gansbeke, and Vincx (1999) (nematodes). The tin capsules containing the copepods and some water

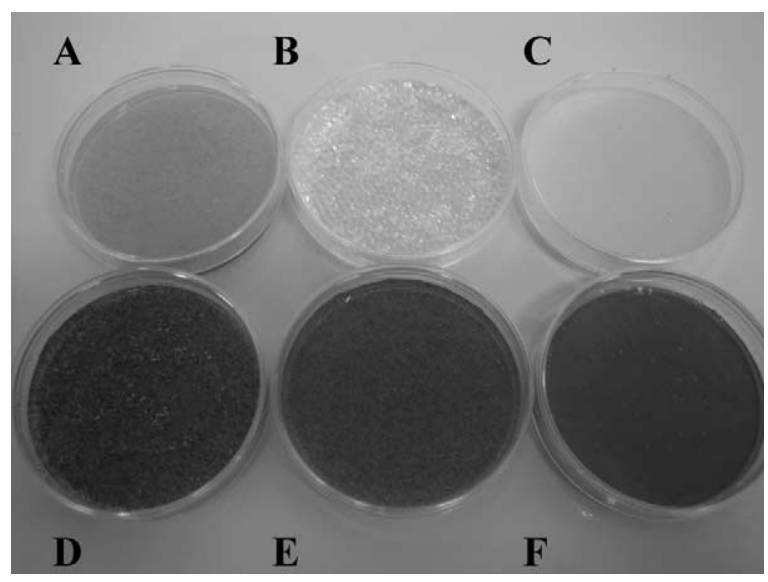

Fig. 2. The various applied sediment treatments: (A) sterile sand, (B) coarse glass beads, (C) fine glass beads, (D) coarse sand, (E) fine sand, (F) silt. 
were dried in an oven at $60^{\circ} \mathrm{C}$ for $12 \mathrm{~h}$. The tin capsules were sent to the UC Davis Stable Isotope Facility (University of California, USA) where measurements of $\delta^{13} \mathrm{C}$ values were done in an isotope ratio mass spectrometer (type Europa Integra). In addition, as the copepod species were of different sizes, the $\delta^{13} \mathrm{C}$ values were initially recalculated (following Middelburg et al., 2000) taking into account individual biomass. For this, incorporation of ${ }^{13} \mathrm{C}$ is reflected as excess (above background) ${ }^{13} \mathrm{C}$ and is expressed as total uptake $(I)$ in $\mathrm{mg}{ }^{13} \mathrm{C}$ ind. ${ }^{-1}$, calculated as the product of excess ${ }^{13} \mathrm{C}(E)$ and individual biomass (organic carbon). $E$ is the difference between the fraction ${ }^{13} \mathrm{C}$ of the control $\left(F_{\text {control }}\right)$ and the sample $\left(F_{\text {sample }}\right): E=F_{\text {sample }}-F_{\text {control }}$, where $F={ }^{13} \mathrm{C} /\left({ }^{13} \mathrm{C}+{ }^{12} \mathrm{C}\right)=R /$ $(R+1)$. The carbon isotope ratio $(R)$ was derived from the measured $\delta^{13} \mathrm{C}$ values as $R=\left(\delta^{13} \mathrm{C} / 1000+1\right) \times R_{\mathrm{VPDB}}$ with $R_{\mathrm{VPDB}}=0.01122372$ as $\delta^{13} \mathrm{C}$ is expressed relative to Vienna Pee Dee Belemnite (VPDB). This total uptake was further standardised and expressed per unit carbon of copepod.

Differences in uptake among the various treatments were tested by means of 2-way analyses of variance (ANOVA) with Statistica 6.0 software (StatSoft Inc., 2001). A posteriori comparisons were carried out with the Tukey test using $95 \%$ confidence limits. Prior to the ANOVA, the Cochran's $C$-test was used to check the assumption of homoscedasticity after transformation of the data.

\section{Results}

There was a significant difference in diatom uptake (expressed as increase in $\delta^{13} \mathrm{C}$, Fig. 3A) among the various treatments, but this uptake did not vary among the two copepod species (2-way ANOVA, species: $p>0.05$, treatment: $p<0.001$, interaction: $p<0.001$ ). The significant interaction term implies that the effect of sediment may differ among species (interaction with species effect), though the effect of sediment on individual species will remain the same. For both $N$. spinipes and $P$. fulvofasciata, no measurable uptake of diatoms was found for the treatment with silty sediment. The corresponding $\delta^{13} \mathrm{C}$ values were negative (as the control values) and significantly lower than all other treatments (Tukey post hoc test, $p<0.001$ ). For $N$. spinipes, the diatom uptake in treatments without sediment, sterile sand and coarse glass beads was significantly higher than in treatments with fine glass beads (Tukey post hoc test, $p<0.05$ ) and fine sand fractions (Tukey post hoc test, $p<0.05)$. Within the former treatments, copepods showed higher $\delta^{13} \mathrm{C}$ in sediment-free conditions than in the coarse glass beads treatment (Tukey post hoc test, $p<0.001$ ). P. fulvofasciata on the other hand, had a significantly lower $\delta^{13} \mathrm{C}$ (Tukey post hoc test, $p<0.02$ ) than $N$. spinipes in the coarse sand microcosms. Overall, both species showed highest uptake when sediment was absent (Fig. 3A).

Taking into account the biomass of the copepod species (Fig. 3B), the total uptake of carbon per individual differed significantly among species but also between the various treatments (2-way ANOVA, species: $p<0.001$, treatment: $p<0.001$, interaction: $p<0.001$ ). Moreover, there was a significant interaction between both factors, suggesting that a strong effect of sediment might be related to the species tested: the effect of sediment was stronger on the largest grazer P. fulvofasciata (see later). Both species showed no uptake of carbon in silty conditions as isotopic values were identical to controls and did not differ among the species (Tukey post hoc test, $p>0.05$ ). While within treatments, the uptake of diatoms varied significantly between species (Tukey post hoc test, $p<0.01$ ) with higher total uptake per individual for the largest copepod species $P$. fulvofasciata. Only in the 


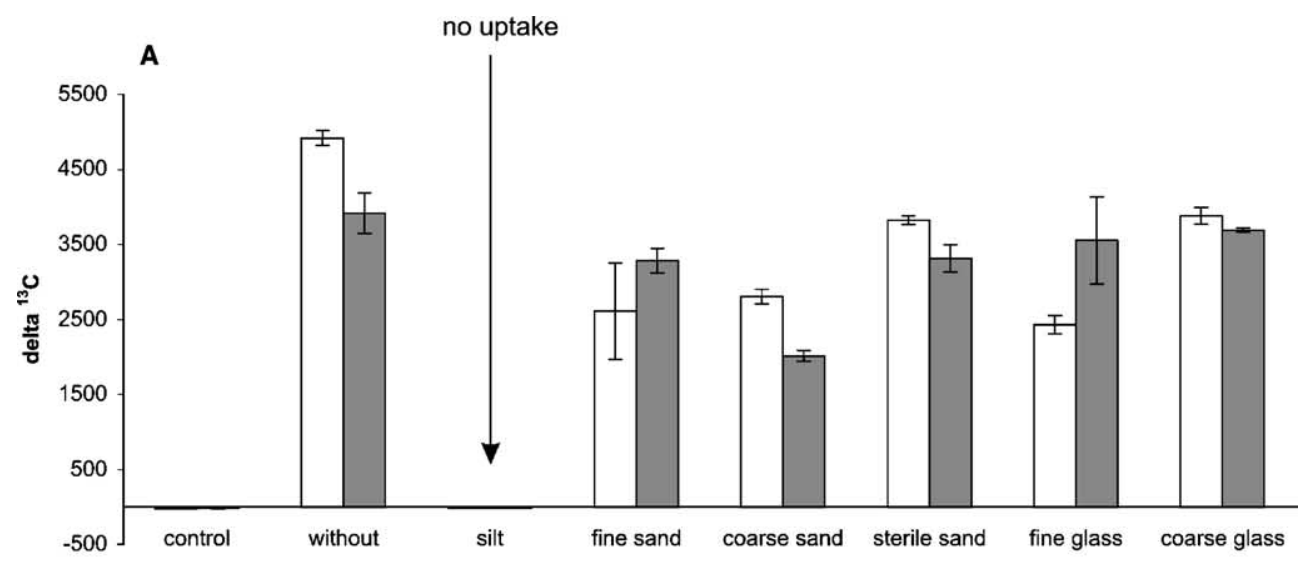

B
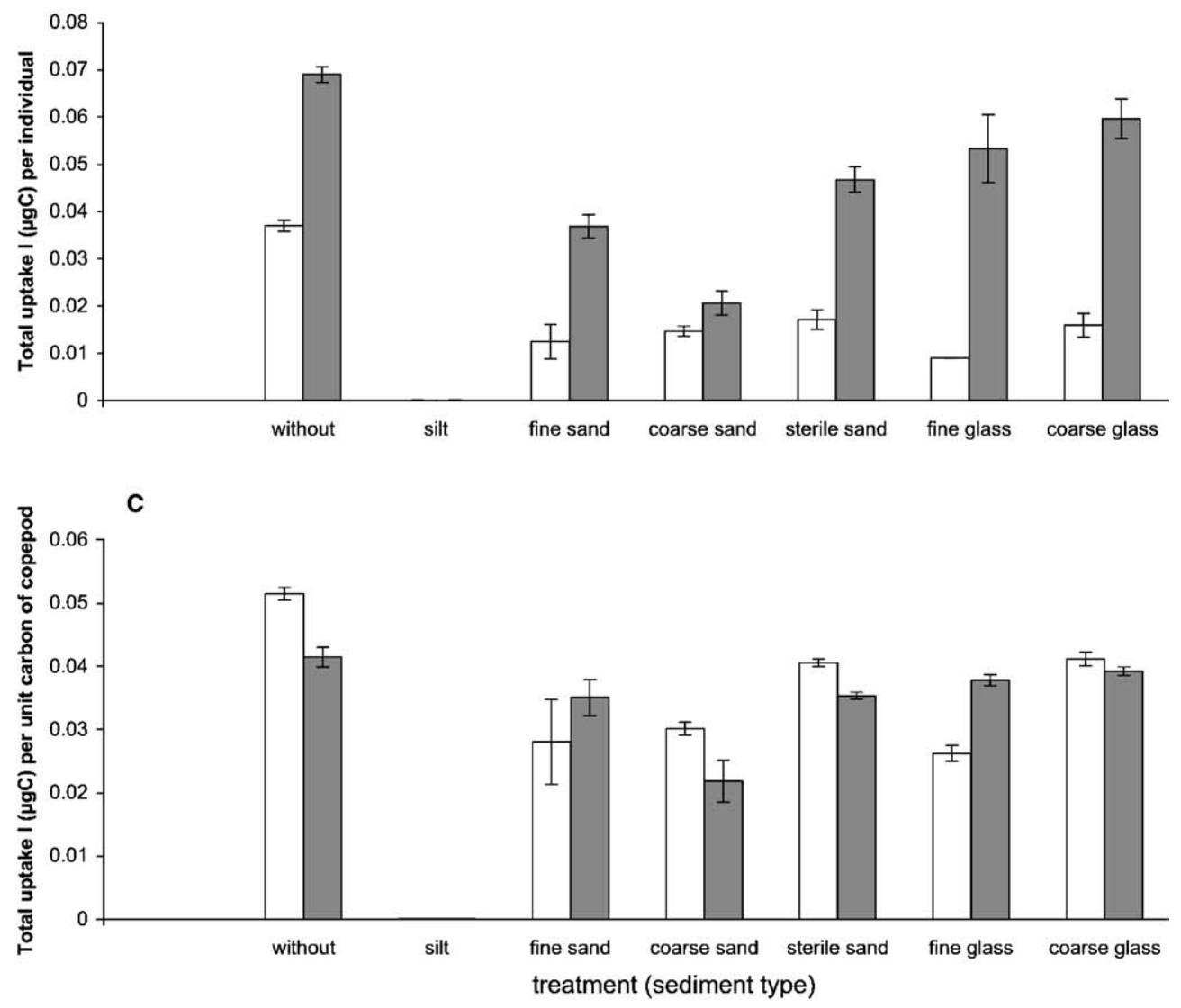

$\square$ Nitokra spinipes $\quad \square$ Paramphiascella fulvofasciata

Fig. 3. Diatom uptake (mean \pm SE) by two harpacticoid copepods for various sediment types expressed as (A) delta ${ }^{13} \mathrm{C}$, (B) total uptake per individual relative to individual biomass, (C) total uptake per unit carbon of copepod. 
coarse sand treatment (Tukey post hoc test, $p>0.05$ ) $P$. fulvofasciata and $N$. spinipes displayed comparable uptake levels per individual.

$N$. spinipes displayed identical uptake patterns in all treatments (Tukey post hoc test, $p>0.05$ ) except for the silty and sediment-free conditions where $N$. spinipes significantly exhibited no or higher uptake (Tukey post hoc test, $p<0.001$ ), respectively. For P. fulvofasciata a significantly lower uptake was found in the fine sand (Tukey post hoc test, $p<0.01$ ) and in the coarse sand treatment (lowest uptake, Tukey post hoc test, $p<0.05$ ) than in environments without sediment.

The standardization of uptake per unit carbon of copepod (Fig. 3C) yielded the same outcome as when uptake was expressed as $\delta^{13} \mathrm{C}$ (Fig. 3A).

\section{Discussion}

Many studies have correlated infaunal invertebrate distributions with sediment grain size, resulting in a generalization of distinct associations between animals and specific sediment types (for review see Snelgrove \& Butman, 1994). In spite of this tight correlation with sediment grain size, most studies provide little insight regarding the mechanisms responsible for such associations. Ravenel and Thistle (1981) related the distribution of two harpacticoid species to sediment where for one species differences in the microbes attached to the sediment particles were of major importance while another species' distribution was governed by factors external to the sediment, i.e., hydrographic conditions or biological interactions. In the present study, we performed controlled laboratory experiments to test the effect of sediment grain size per se and we therefore excluded, e.g., organic contents, microbial populations as possible interfering factors. The use of ${ }^{13} \mathrm{C}$ prelabeled diatoms allowed us to follow the effects of sediment grain size on grazing of diatoms by two harpacticoid copepod species.

As the complete organism (including its gut contents) was used to measure the uptake of enriched diatoms in different sediment conditions, the obtained results might refer to gut contents rather than to effective assimilation of labeled carbon by the copepods. De Troch et al. (2005) gave evidence of an increase or a stagnation of $\delta^{13} \mathrm{C}$ after emptying guts, suggesting that the gut contents were of minor importance in the total ${ }^{13} \mathrm{C}$ measurements. Since we followed the same experimental set-up here, we would not expect any obvious effect of gut content. One can consider the importance of labeled micro-organisms attached to the body and appendages of the copepods in biasing measurements of true assimilation of labeled carbon. Carman (1990) found that uptake of ${ }^{14} \mathrm{C}$-labeled diatoms by copepods was almost entirely due to grazing on labeled microalgae.

As noticed earlier, the artificial nature of any experimental set-up imposes difficulties in seeing the true picture. In the present study, all treatments were conducted with clearly distinct types of sediment grain size fractions, while mixes between different fractions reflecting a more natural situation (e.g., sediments of different silt/sand content) were not considered. Additional biogenic structuring elements (e.g., macroalgae, plants) were excluded in the feeding experiments in order to test only the effect of sediment characteristics per se. Harpacticoid copepod densities in the experimental units were rather low (9-14 individuals per $10 \mathrm{~cm}^{2}$ ) in comparison to natural conditions. The food density used in our experiment was based on counts of diatom cells in faecal pellets (De Troch, unpublished). We estimated that an average of 125,000 diatom cells/copepod would correspond to food limitation, so there was sufficient food available in our experimental units. There were no 
data on diatom concentration in the field situation, however it is well known that diatom biofilms are well-established on intertidal mudflats (e.g., Bellinger, Abdullahi, Gretz, \& Underwood, 2005; Decho, 2000; Herlory, Guarini, Richard, \& Blanchard, 2004) though these biofilms are very variable depending on light conditions (pers. observ.).

Uptake of diatoms by harpacticoid copepods in different sediment types was measurable for all treatments, except for the silty sediment microcosm with negative $\delta^{13} \mathrm{C}$ values for both copepod species. The values were not different from the natural isotopic signature of the copepods, as found in the controls. Consequently, this implies that there had been no grazing on diatoms in sediment grain sizes smaller than $63 \mu \mathrm{m}$. Moreover, we observed that all individuals of both species in the silt situation had empty guts. Together with the lack of assimilated label, this indicates that the copepods did not feed on the diatoms, starved and died soon after the start of the experiment while in the other treatments the survival rate was $100 \%$. In addition, we also noticed that in those microcosms, the copepods were partially or totally covered by silt. In contrast to other harpacticoid species (e.g., Canuella perplexa) that are able to migrate vertically within muddy sediments (silt percentage of 36$58.4 \%$ ) between the surface and a depth of $3 \mathrm{~cm}$ (Buffan-Dubau, de Wit, \& Castel, 1996), N. spinipes and $P$. fulvofasciata seem to encounter mobility difficulties in very fine sediment. Apparently, the smallest silt grains attached themselves to the copepod carapaces, - e.g., during grazing activities in the surface layers of the sediment - formed sticky aggregations and probably hindered the functioning of the feeding apparatus and/or movements of the copepods in search for food. These observations denote that both $N$. spinipes and $P$. fulvofasciata are not well-adapted to graze on diatoms in silty or muddy conditions. It is possible that both $N$. spinipes and P. fulvofasciata dwell in highly silty environments, but that they do not feed on biomat forming diatoms in those conditions. Probably other prey items and detrital matter serve as complementary food when the copepods are not able to feed on diatoms embedded in fine-grained sediment. As we used a $100 \%$ silt substrate in contrast to the wide range of silt content in natural mudflats, this outcome is not surprising.

On the other hand, both species could graze on diatoms or microbial biofilms when the sediment silt percentage is decreasing and more sandy fractions are encountered. Sponaugle and Lawton (1990) noted that predators may switch to other prey types when their efficiency in finding and handling prey is influenced by differences in sediment characteristics. For example, changes in sedimentary composition are known to affect or alter predator-prey interactions in some nematode species (both aquatic and terrestrial) (Elliot, Anderson, Coleman, \& Cole, 1980; Galluci et al., in press; Mikola \& Sulkava, 2001). Galluci et al. (in press) found that predation by the nematode Enoploides longispiculosus (also from Paulina intertidal flat) was impeded or reduced due to slight differences in sediment properties, mainly silt content. This predacious nematode was even incapable of catching prey in sediments containing $>12 \%$ silt. In addition to mobility restrictions, the proportion of silt determines the degree of sediment pore space filling, and thus the upper size limits of interstitial species (Schwinghamer, 1981). However, we expect diatom grazers to be mainly active at the sediment surface as a typical mudflat biofilm is most pronounced near the sediment surface, where diatoms and other phototrophs give rise to an efficient primary production (e.g., Decho, 2000; Guarini, Blanchard, Gros, Gouleau, \& Bacher, 2000). In essence, the feeding efficiency of the two harpacticoid copepod species may be favoured when grain size is increasing, as seen in our experiment.

The most striking outcome of our experiment was the fact that both harpacticoids showed the highest uptake of diatoms in a sediment-free environment. This suggests that 
they performed a higher grazing efficiency and had better access to the diatom biofilm on the bottom of the petri-plate. Obviously, the accessibility of a biofilm for grazers is related to the structure of the biofilm. In natural conditions, recently disturbed sediments are covered by mats over periods of weeks to months with these mats forming coatings on the surfaces of the sediment particles that can extend meters across the surface (Decho et al., 2003). These biofilms consist of microbial cells (non-photosynthetic and photosynthetic bacteria and microalgae) embedded within a secreted matrix of extracellular polymeric substances (EPS) (Costerton, Lewandowski, Caldwell, Korber, \& Lappin-Scott, 1995). The EPS matrix of biofilm forms sticky coatings on individual sediment particles and detrital surfaces, which act as a stabilizing anchor to buffer cells and their extracellular processes during frequent physical stresses (e.g., changes in salinity and temperature, UV irradiation, desiccation) (Decho, 2000). Especially intertidal mudflats, where the test harpacticoid species were collected from, are known for these extended biofilms of microphytobenthos (e.g., Bellinger et al., 2005 Decho, 2000; Herlory et al., 2004).

In addition to the structure of the biofilm, the quality of the composing bacteria and microalgae is important (Cruz-Rivera \& Hay, 2000) and may influence grazing selectivity. Our results show that the offered diatoms are a suitable food source for these grazers, though no alternatives were offered. When the diatom biofilm is well-established, obviously not on pure silt, these copepods are efficient grazers. As we used non-axenic diatom cultures, the associated bacteria and their microbial secretions might be different depending on the substrate. Apparently, the substrate (sediment particles or plastic bottom of a petriplate) largely determines both structure, quality of the biofilm and concomitantly, its accessibility and preference for grazers.

Our results suggest that both $N$. spinipes and $P$. fulvofasciata are not the best diatom grazers in sediment as their uptake increases when sediment is absent. Both harpacticoid copepod species have limited swimming capacities and do not exert long stays in the water column. These copepods may be forced towards the sediment due to competition or are attracted because of the high primary production at the sediment surface.

Of course, several factors may cause alteration of feeding behaviour. Pace and Carman (1996) warned against possible differences between grazing behaviour in natural versus laboratory situations. Food availability and sedimentary characteristics in the experimental units do not reflect the natural situation. Both copepods are forced to feed only on two biomat forming benthic diatoms of sizes smaller than $20 \mu \mathrm{m}$, this in contrast to high food concentrations and diversity in natural habitats and our cultures (see Section 2).

Individual uptake of carbon by $P$. fulvofasciata was 1.5 to even six times higher than $N$. spinipes, following the logical outcome with the larger animal - i.e., P. fulvofasciata - taking the highest amount of carbon. However, the total uptake per unit carbon of copepod is not different for both species. When both copepods are considered to be of comparable size and carbon content (see Section 2), this means that both species assimilate same amounts of carbon per unit carbon of copepod, but that $P$. fulvofasciata has to take up more diatoms regarding its lower assimilation efficiency. In addition, previous experiments indicated that $P$. fulvofasciata selected smaller diatom cells (De Troch et al., unpublished data) which might explain the uptake of more cells.

To our knowledge, no fundamental research has been done considering feeding behaviour and mechanisms of both harpacticoid species in relation to sediment. Hicks and Coull (1983, \& references herein) defined two basic feeding modes, surface browsing and filtration, as recognised in harpacticoids. Marcotte (1977) had made an earlier classification, 
dividing surface-feeding harpacticoids into four categories: (1) point-feeders, (2) line-feeders, (3) plane-sweepers and sand-filers and, (4) solid-feeders. Our results showed grazing on diatoms when sediment was absent or when sediment grains were larger than $125 \mu \mathrm{m}$. Most likely, sediment grains of those bigger dimensions are easily grasped by the copepods, manipulated by the appendages and followed by removal of diatom biofilms. Hereby, the copepods could actively search for those alimentary patches by digging and wandering in and on the sediment. Diatom biofilms are best grazed upon in conditions with no sediment, since the copepods do not encounter problems in searching food and are able to graze easily on the large, flat bottom surface of the petri-plates. As such, we assume that $N$. spinipes and $P$. fulvofasciata are interstitial plane-sweepers and/or sand-filers since these terms denote species that sweep food into their mouths from large planar surfaces (of organic material) with the second antennae or scrape their food from faults and depressions on sand grains. Hicks and Coull (1983, \& references herein) report that in fine to medium sands, where the median diameter and associated granulometry allows for an interstitial existence, two general harpacticoid groups occur, i.e. interstitial forms (mesopsammon) and epibenthic forms (epipsammon). In general, interstitial harpacticoids are small, vermiform and elongate animals that occupy the interstices of sands by wiggling around and between the particles. On the other hand, epibenthic forms are typically large, live on the surface of the sediment and often have the ability to swim. As sediment was lacking in our copepod stock cultures, $N$. spinipes and $P$. fulvofasciata were mainly found within the fluffy detrital and algal matter.

Feeding behaviour and functional morphology of oral appendages of $N$. spinipes and $P$. fulvofasciata are still poorly understood. As a consequence, a functional interpretation of feeding mechanisms of both harpacticoids remains highly speculative. A further generalisation of our results towards a larger group of harpacticoids would be inappropriate in view of our limited knowledge on the ecology of the test organisms and our first indications towards species-specific grazing behaviour (De Troch et al., 2005). The technique of tracing diatom uptake by means of stable isotopes offers an adequate approach to unravel the feeding ecology of harpacticoid copepods. High resolution video technique provides also excellent assessment of feeding behaviour, as shown by Marcotte (1977) in the preycrushing species Tisbe furcata, however the application of this technique is most unlikely to follow interstitial or sediment-dwelling grazers in sedimentary conditions.

This is the first laboratory experiment that measures the uptake of diatoms by harpacticoid copepods in the presence of sediment. We underlined the subtle equilibrium between grazers and main primary producers and the role of sediment for this important link. Our results suggest that increased fine sediment concentrations may be adverse for grazers and not only for suspension feeders. Although both test organisms were collected from fine sediment on mudflats, characterised by fine sediments and a well-developed biofilm, their grazing efficiency decreased dramatically in a silty environment. This suggests that they are attracted to this rich food source in spite of the unfavourable sedimentary conditions. Moreover, the strong negative effect of silt on the grazer's efficiency as shown here might have important implications for the effect of siltation of tidal flats due to, e.g., human activities.

\section{Acknowledgements}

The first author is a postdoctoral fellow with the Fund for Scientific Research (FWOFlanders). These experiments were conducted within the frame of FWO research project 
G.0313.04. Danielle Schram kindly conducted sediment granulometric analysis. Marisa Wyckmans assisted in sorting copepods from the cultures. Tom Moens gave stimulating comments to the study. Three anonymous referees gave constructive comments and valuable suggestions in order to improve the manuscript.

\section{References}

Bellinger, B. J., Abdullahi, A. S., Gretz, M. R., \& Underwood, G. J. C. (2005). Biofilm polymers: relationship between carbohydrate biopolymers from estuarine mudflats and unialgal cultures of benthic diatoms. Aquatic Microbial Ecology, 38, 169-180.

Buffan-Dubau, E., \& Carman, K. R. (2000). Diel feeding behavior of meiofauna and their relationships with microalgal resources. Limnology and Oceanography, 45, 381-395.

Buffan-Dubau, E., de Wit, R., \& Castel, J. (1996). Feeding selectivity of the harpacticoid copepod Canuella perplexa in benthic muddy environments demonstrated by HPLC analyses of chlorin and carotenoid pigments. Marine Ecology Progress Series, 137, 71-82.

Carman, K. R. (1990). Mechanisms of uptake of radioactive labels by meiobenthic copepods during grazing experiments. Marine Ecology Progress Series, 68, 71-83.

Carman, K. R., \& Thistle, D. (1985). Microbial food partitioning by three species of benthic copepods. Marine Biology, 88, 143-148.

Chepurnov, V. A., Mann, D. G., Vyverman, W., Sabbe, K., \& Danielidis, D. B. (2002). Sexual reproduction, mating system, and protoplast dynamics of Seminavis (Bacillariophyta). Journal of Phycology, 38, 1004-1019.

Costerton, J. W., Lewandowski, Z., Caldwell, D. E., Korber, D. R., \& Lappin-Scott, H. M. (1995). Microbial biofilms. Annual Review of Microbiology, 49, 711-745.

Cruz-Rivera, E., \& Hay, M. E. (2000). Can quantity replace quality? Food choice, compensatory feeding, and fitness of marine mesograzers. Ecology, 81, 201-219.

Decho, A. W. (2000). Microbial biofilms in intertidal systems: an overview. Continental Shelf Research, $20,1257-1273$.

Decho, A. W., Kawaguchi, T., Allison, M. A., Louchard, E. M., Reid, R. P., Stephens, F. C., et al. (2003). Sediment properties influencing upwelling spectral reflectance signatures: The "biofilm gel effect". Limnology and Oceanography, 48, 431-443.

De Troch, M., Mees, J., \& Wakwabi, E. O. (1998). Diets of abundant fishes from beach seine catches in seagrass beds of a tropical bay (Gazi Bay, Kenya). Belgian Journal of Zoology, 128, 135-154.

De Troch, M., Steinarsdóttir, M. B., Chepurnov, V., \& Ólafsson, E. (2005). Grazing on diatoms by harpacticoid copepods: species-specific density-dependent uptake and microbial gardening. Aquatic Microbial Ecology, 39, $135-144$.

Elliot, E. T., Anderson, R. V., Coleman, D. C., \& Cole, C. V. (1980). Habitable pore space and microbial trophic interactions. Oikos, 35, 327-335.

Ellis, J., Cummings, V., Hewitt, J., Thrush, S., \& Norkko, A. (2002). Determining effects of suspended sediment on condition of a suspension feeding bivalve (Atrina zelandica): results of a survey, a laboratory experiment and a field transplant experiment. Journal of Experimental Marine Biology and Ecology, 267, 147-174.

Fetcher, A., Thistle, D., Arlt, G., Suderman, K., \& Vopel, K. (2004). Do harpacticoids (Copepoda) use waterborne cues to aid in locating food parcels? Marine Ecology, 25, 217-223.

Galluci, F., Steyaert, M., \& Moens, T. (in press). Can field distributions of marine predacious nematodes be explained by sediment constraints on their foraging success? Marine Ecology Progress Series.

Guarini, J. M., Blanchard, G. F., Gros, P., Gouleau, D., \& Bacher, C. (2000). Dynamic model of the short-term variability of microphytobenthic biomass on temperate intertidal mudflats. Marine Ecology Progress Series, 195, 291-303.

Guidi, L. D. (1984). The effect of food composition on ingestion, development and survival of a harpacticoid copepod, Tisbe cucumariae. Journal of Experimental Marine Biology and Ecology, 84, 101-110.

Guillard, R. L. (1975). Culture of phytoplankton for feeding marine invertebrates. In W. L. Smith \& M. H. Chandley (Eds.), Culture of marine invertebrate animals (pp. 29-60). New York: Plenum Press.

Heip, C. H. R., Goosen, N. K., Herman, P. M. J., Kromkamp, J., Middelburg, J. J., \& Soetaert, K. (1995). Production and consumption of biological particles in temperate tidal estuaries. Oceanography and Marine Biology. An Annual Review, 33, 1-150.

Herlory, O., Guarini, J.-M., Richard, P., \& Blanchard, G. F. (2004). Microstructure of microphytobenthic biofilm and its spatio-temporal dynamics in an intertidal mudflat (Aiguillon Bay, France). Marine Ecology Progress Series, 282, 33-44. 
Hicks, G. R. F., \& Coull, B. C. (1983). The ecology of marine meiobenthic harpacticoid copepods. Oceanography and Marine Biology: An Annual Review, 21, 67-175.

Hillebrand, H., Dürselen, C.-D., Kirschtel, D., Pollingher, U., \& Zohary, T. (1999). Biovolume calculation for pelagic an benthic microalgae. Journal of Phycology, 35, 403-424.

Lopez, G. W. (1982). Short-term population dynamics of Tisbe cucumariae (Copepoda: Harpacticoida). Marine Biology, 68, 333-341.

Marcotte, B. M. (1977). An introduction to the architecture and kinematics of harpacticoid (Copepoda) feeding: Tisbe furcata (Baird, 1837). Mikrofauna des Meeresbodens, 61, 183-196.

Middelburg, J. J., Barranguet, C., Boschker, H. T. S., Herman, P. M. J., Moens, T., \& Heip, C. H. R. (2000). The fate of intertidal microphytobenthos carbon: An in situ ${ }^{13} \mathrm{C}$-labeling study. Limnology and Oceanography, 45, $1224-1234$.

Mikola, J., \& Sulkava, P. (2001). Responses of microbial-feeding nematodes to organic matter distribution and predation in experimental soil habitat. Soil Biology and Biochemistry, 33, 811-817.

Moens, T., Van Gansbeke, D., \& Vincx, M. (1999). Linking estuarine nematodes to their suspected food. A case study from the Westerschelde Estuary (south-west Netherlands). Journal of the Marine Biology Association of the United Kingdom, 79, 1017-1027.

Montagna, P. A. (1995). Rates of metazoan meiofaunal microbivory: a review. Vie et Milieu, 45, 1-9.

Mourelatos, S., Rougier, C., \& Lacroix, G. (1992). Radiotracer losses due to freezing in formalin of carbon-14labeled cladocerans. Archiv für Hydrobiologie, 126, 239-253.

Pace, M. C., \& Carman, K. R. (1996). Interspecific differences among meiobenthic copepods in the use of microalgal food sources. Marine Ecology Progress Series, 143, 77-86.

Ravenel, W. S., \& Thistle, D. (1981). The effect of sediment characteristics on the distribution of two subtidal harpacticoid copepod species. Journal of Experimental Marine Biology and Ecology, 50, 289-301.

Reise, K. (2002). Sediment mediated species interactions in coastal waters. Journal of Sea Research, 48, 127-141.

Rieper, M. (1978). Bacteria as food for marine harpacticoid copepods. Marine Biology, 45, 337-345.

Rieper, M. (1982). Feeding preferences of marine harpacticoid copepods for various species of bacteria. Marine Ecology Progress Series, 7, 303-307.

Rieper, M., \& Flotow, C. (1981). Feeding experiments with bacteria, ciliates and harpacticoid copepods. Kieler Meeresforschungen, 39, 370-375.

Round, F. E., Crawford, R. M., \& Mann, D. G. (1990). The diatoms: biology and morphology of the genera. New York: Cambridge University Press.

Schwinghamer, P. (1981). Characteristic size distributions of integral benthic communities. Canadian Journal of Fisheries and Aquatic Sciences, 38, 1255-1263.

Seifried, S., \& Dürbaum, J. (2000). First clear case of carnivory in marine Copepoda Harpacticoida. Journal of Natural History, 34, 1595-1618.

Smith, D. J., \& Underwood, G. J. C. (1998). Exopolymer production by intertidal epipelic diatoms. Limnology and Oceanography, 43, 1578-1591.

Snelgrove, P. V. R., \& Butman, C. A. (1994). Animal-sediment relationships revisited: cause versus effects. Oceanography and Marine Biology: An Annual Review, 32, 111-177.

Sogard, S. M. (1984). Utilization of meiofauna as a food source by a grassbed fish, the spotted dragonet Callionymus pauciradiatus. Marine Ecology Progress Series, 17, 183-191.

Sponaugle, S., \& Lawton, P. (1990). Portunid crab predation on juvenile hard clams: effects of substrate type and prey density. Marine Ecology Progress Series, 67, 43-53.

StatSoft, Inc. (2001). STATISTICA (data analysis software system), version 6.0. Available from www.statsoft.com.

Underwood, G. J. C., \& Kromkamp, J. (1999). Primary production by phytoplankton and microphytobenthos in estuaries. Advances in Ecological Research, 29, 93-153.

Underwood, G. J. C., \& Paterson, D. M. (1993). Recovery of intertidal benthic diatoms form biocide treatment and associated sediment dynamics. Journal of the Marine Biological Association of the United Kingdom, 73, 2545. 